\title{
Borehole Data Package for Well 299-W15-41 at Single-Shell Tank Waste Management Area TX-TY
}

D. G. Horton

F. N. Hodges

May 2000

Prepared for

the U.S. Department of Energy

under Contract DE-AC06-76RLO 1830

Pacific Northwest National Laboratory

Richland, Washington 99352 



\section{Contents}

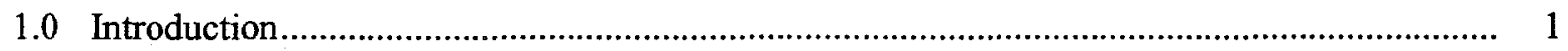

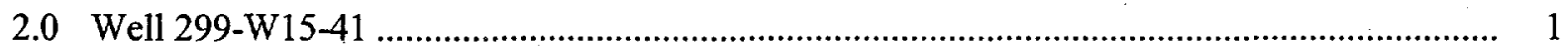

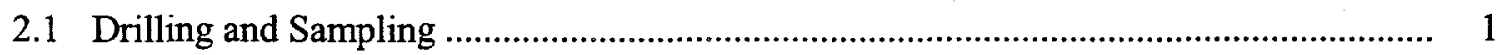

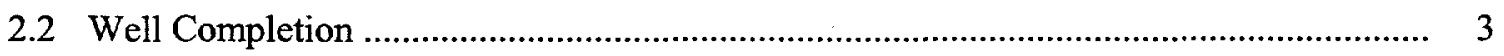

2.3 Well Development and Pump Installation ................................................................. 4

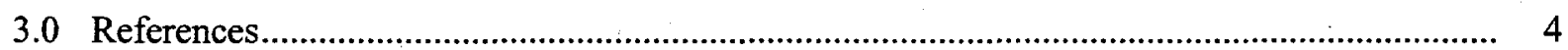

Appendix A - Well Construction and Completion Documentation ......................................... A.1

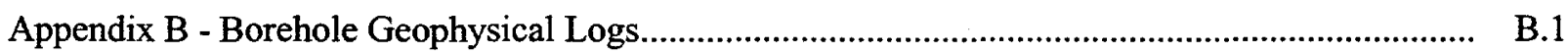

\section{Figure}

1 Map of WMA TX-TY and Locations of Wells in the Groundwater Monitoring Network....... 2

\section{Table}

1 Survey Data for Well 299-W15-41 at Waste Management Area TX-TY................................ 


\section{DISCLAIMER}

This report was prepared as an account of work sponsored by an agency of the United States Government. Neither the United States Government nor any agency thereof, nor any of their employees, make any warranty, express or implied, or assumes any legal liability or responsibility for the accuracy, completeness, or usefulness of any information, apparatus, product, or process disclosed, or represents that its use would not infringe privately owned rights. Reference herein to any specific commercial product, process, or service by trade name, trademark, manufacturer, or otherwise does not necessarily constitute or imply its endorsement, recommendation, or favoring by the United States Government or any agency thereof. The views and opinions of authors expressed herein do not necessarily state or reflect those of the United States Government or any agency thereof. 


\section{DISCLAIMER}

Portions of this document may be illegible in electronic image products. Images are produced from the best available original document. 


\subsection{Introduction}

One new Resource Conservation and Recovery Act (RCRA) groundwater monitoring well was installed at the single-shell tank farm Waste Management Area (WMA) TX-TY during December 1999 and January 2000 in fulfillment of Tri-Party Agreement (Ecology 1996) milestone M-24-43. The well is 299-W15-41 and is located south of the 241-TX tank farm and south of $20^{\text {th }}$ Street in the 200 West Area. Figure 1 shows the locations of all wells in the WMA TX-TY monitoring network.

The new well was constructed to the specifications and requirements described in Washington Administrative Code (WAC) 173-160 and WAC 173-303, the groundwater monitoring plan for WMA TX-TY (Caggiano and Goodwin 1991), the assessment plan for WMA TX-TY (Caggiano and Chou 1993), and the description of work for well drilling and installation. ${ }^{1}$

This document compiles information on the drilling and construction, well development, pump installation, and sediment testing applicable to well 299-W15-41. Appendix A contains the geologist's $\log$, the Well Construction Summary Report, and Well Summary Sheet (as-built diagram) and Appendix $\mathrm{B}$ contains borehole geophysical logs. Additional documentation concerning well construction is on file with Bechtel Hanford, Inc., Richland, Washington.

English units are used in this report because that is the system of units used by drillers to measure and report depths and well construction details. Conversion to metric is made by multiplying feet by 0.3048 to obtain meters or multiplying inches by 2.54 to obtain centimeters.

\subsection{Well 299-W15-41}

\subsection{Drilling and Sampling}

Well 299-W15-41 was started with a sonic drill rig and casing hammer. Temporary 11 3/4-in.outside-diameter, carbon steel casing was placed from 0 to $55 \mathrm{ft}$ below ground surface (bgs). An air rotary rig finished the drilling from $55 \mathrm{ft}$ to a total depth of $239 \mathrm{ft}$ bgs with temporary $85 / 8$-in.-outsidediameter carbon steel casing. At about $40 \mathrm{ft}$ bgs, 5 gal of water were added to the borehole during drilling.

Sediments encountered during drilling were predominantly sand and sandy gravel of the Hanford formation from the surface to about $93 \mathrm{ft} \mathrm{bgs}$; Plio-Pliestocene silty sands with varying caliche content

1 Letter from R. M. Smith, Pacific Northwest National Laboratory, Richland, Washington, to G. C. Henckel, Bechtel Hanford Inc., dated May 26, 1999, "Description of Work for Drilling of CY 1999 RCRA Groundwater Monitoring Wells." 


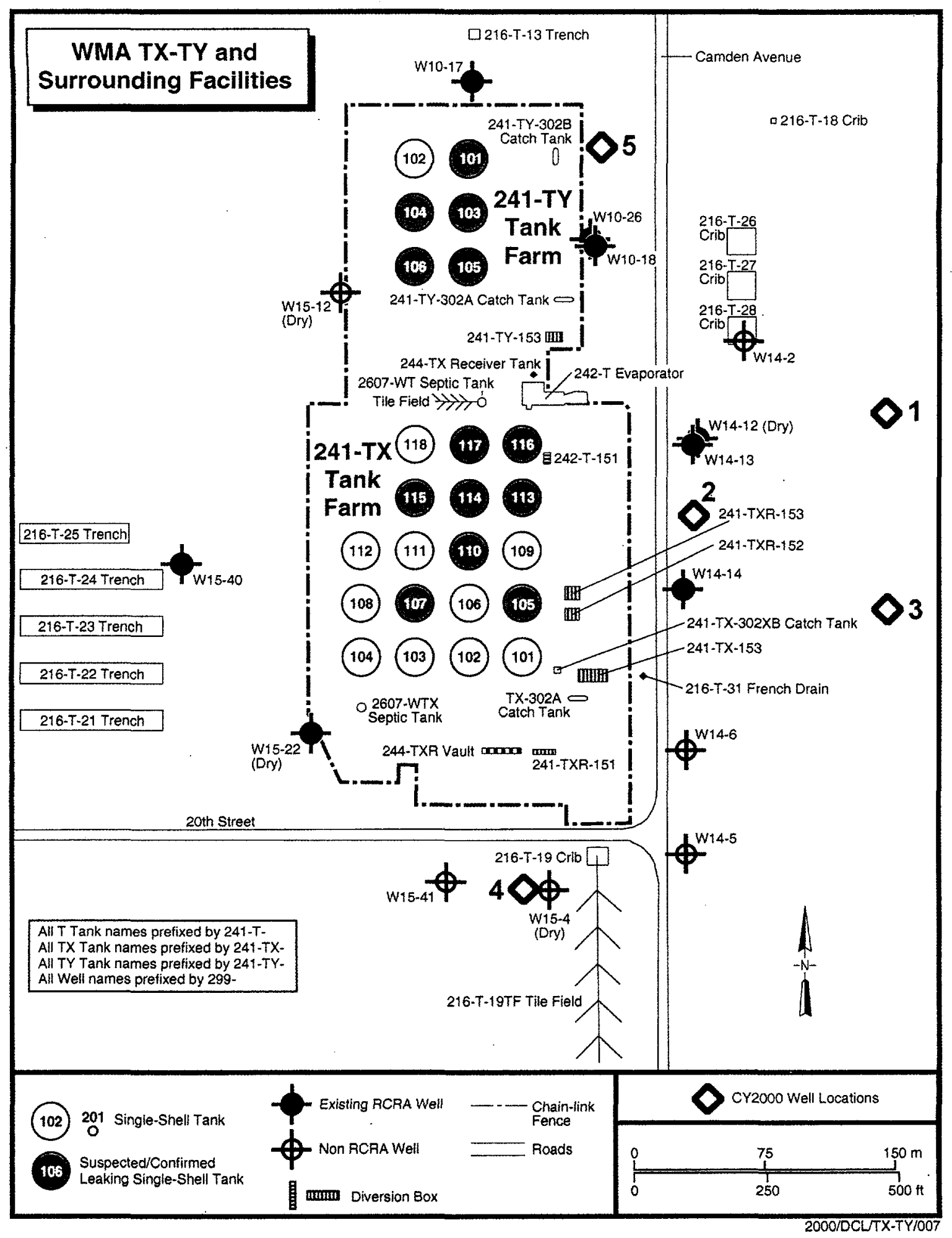

Figure 1. Map of WMA TX-TY and Locations of Wells in the Groundwater Monitoring Network 
from 93 to about $120 \mathrm{ft}$ bgs (depths based on geophysical log correlation); and sandy gravel and gravally sand of the Ringold Formation from 120 to $239 \mathrm{ft}$ bgs (total depth). A geologist's log is included in Appendix A.

Grab samples of sediment for geologic description and archive were collected at approximate $5 \mathrm{ft}$ intervals from $55 \mathrm{ft}$ to total depth. Also, three split spoon samples were collected from 219 to 221,230 to 230.7 , and 238 to $239 \mathrm{ft}$ bgs.

The borehole and drill cuttings were monitored regularly for organic vapors and radionuclide contaminants. No organic contaminants were noted. Radiologic readings reached 1000 to $1500 \mathrm{dpm}$ at a silt lens at about $44.5 \mathrm{ft}$ depth. The borehole was drilled as low risk below $55 \mathrm{ft}$.

The well was geophysically logged through the temporary casing using high resolution, spectral gamma-ray and neutron moisture instrumentation on January 6 and 7,2000. No man-made radionuclides were detected. The geophysical logs are in Appendix B.

\subsection{Well Completion}

The permanent casing and screen were installed in well 299-W15-41 during January 2000. A 4-in.inner-diameter, stainless steel, continuous wire-wrap ( 0.01 in. slot) screen was set from 230.94 to $215.92 \mathrm{ft}$ bgs. The top of the well screen is about $2.5 \mathrm{ft}$ below the water table because the casing string fell during installation. The permanent casing is 4-in.-inner-diameter, stainless steel from $215.92 \mathrm{ft}$ bgs to $2.0 \mathrm{ft}$ above ground surface. The bottom of the screen has a $4 \mathrm{in}$. PVC end cap to facilitate later deepening of the well if necessary.

The sand pack is 20 to 40 mesh silica sand from 238.1 to $206.6 \mathrm{ft}$ bgs. The annular seal is Portland cement with bentonite from 206.6 to $200.1 \mathrm{ft}$ bgs; \#8 mesh granular bentonite from $200.1 \mathrm{ft}$ to $13.5 \mathrm{ft}$ bgs; and Portland cement with bentonite from $13.5 \mathrm{ft}$ to the surface. A $4 \mathrm{ft}$ by $4 \mathrm{ft}$ by 6 in. concrete pad was placed around the well at the surface. A protective casing with locking cap, four protective steel posts, and a brass marker stamped with the well number were set into the concrete. The Well Construction Summary Report and the Well Summary Sheet (as-built) are included in Appendix A. After well completion, static water level was $213.3 \mathrm{ft}$ bgs on January $17,2000$.

The vertical and horizontal coordinates of the well were surveyed in March 2000. The horizontal position of the well was determined by Global Positioning System observations referenced to horizontal control stations established by Rogers Surveying, Inc., Richland, Washington. The coordinates are Washington Coordinate System, South Zone, NAD83(91) datum. Vertical datum is NAVD 1988 and is based on existing bench marks established by the U.S. Corps of Engineers. Survey data are included in Table 1. 
Table 1. Survey Data for Well 299-W15-41 at Waste Management Area TX-TY

\begin{tabular}{|c|c|c|c|c|}
\hline Well Name & $\begin{array}{l}\text { Easting } \\
\text { m (ft) }\end{array}$ & $\begin{array}{c}\text { Northing } \\
\mathbf{m}(\mathrm{ft})\end{array}$ & $\begin{array}{c}\begin{array}{c}\text { Elevation } \\
\mathrm{m}(\mathrm{ft})\end{array} \\
\end{array}$ & \\
\hline \multirow{3}{*}{ 299-W15-41 } & $\begin{array}{l}566,757.587 \\
(1,859,435.294)\end{array}$ & $\begin{array}{l}136,031.682 \\
(466,296.823)\end{array}$ & & Center of Casing \\
\hline & & & $\begin{array}{l}203.484 \\
(667.596) \\
\end{array}$ & "X" on Casing \\
\hline & $\begin{array}{l}566,757.583 \\
(1,859,435.281)\end{array}$ & $\begin{array}{l}136,031.993 \\
(446,297.844)\end{array}$ & $\begin{array}{l}202.788 \\
(665.313)\end{array}$ & Brass Cap \\
\hline
\end{tabular}

\subsection{Well Development and Pump Installation}

Well 299-W15-41 was developed on January 14, 2000. A temporary, $3 \mathrm{hp}$, submersible pump was used to remove approximately $2,300 \mathrm{gal}$ of formation water from the well at $26 \mathrm{gal} / \mathrm{min}$. Pump intake was at $227.95 \mathrm{ft}$ bgs. The approximate drawdown was $3.2 \mathrm{ft}$ and the final turbidity was $4.30 \mathrm{NTU}$.

A dedicated Hydrostar sampling pump was installed in well 299-W15-41 on January 18,2000 . The sampling pump intake is at $219 \mathrm{ft}$ bgs or about $5.7 \mathrm{ft}$ below the water table.

\subsection{References}

Caggaino, J. A., and C. J. Chou. 1993. Interim-Status Groundwater Quality Assessment Plan for the Single-Shell Tank Waste Management Areas T and TX-TY. WHC-SD-EN-AP-132, Rev. 0, Westinghouse Hanford Company, Richland, Washington.

Caggiano, J. A., and S. M. Goodwin. 1991. Interim Status Groundwater Monitoring Plan for the SingleShell Tanks. WHC-SD-EN-AP-012, Rev. 1. Westinghouse Hanford Company, Richland, Washington.

Ecology - Washington State Department of Ecology, U.S. Environmental Protection Agency, and U.S. Department of Energy. 1996. Hanford Federal Facility Agreement and Consent Order. Document No. 89-10, Rev. 4 (The Tri-Party Agreement), Ecology, Olympia, Washington.

RCRA - Resource Conservation and Recovery Act. 1976. Public Law 94-580, as amended, 90 Stat. 2795,42 USC 6901 et seq.

WAC 173-160, Washington Administrative Code. Minimum Standards for Construction and Maintenance of Wells. Olympia, Washington.

WAC 173-303, Washington Administrative Code. Dangerous Waste Regulations. Olympia, Washington. 
Appendix A

Well Construction and Completion Documentation 


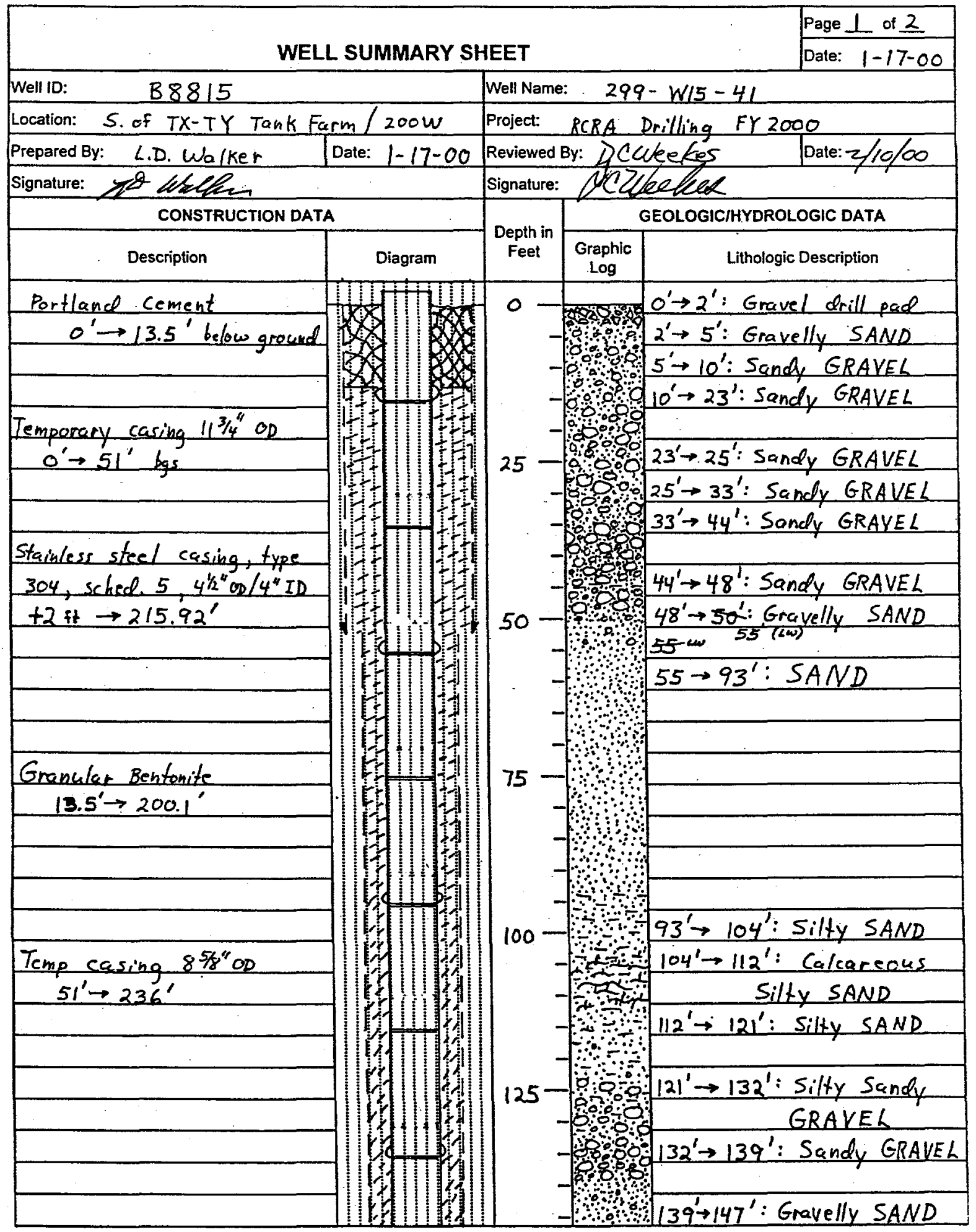

BHI-EE-189 (12/97) 


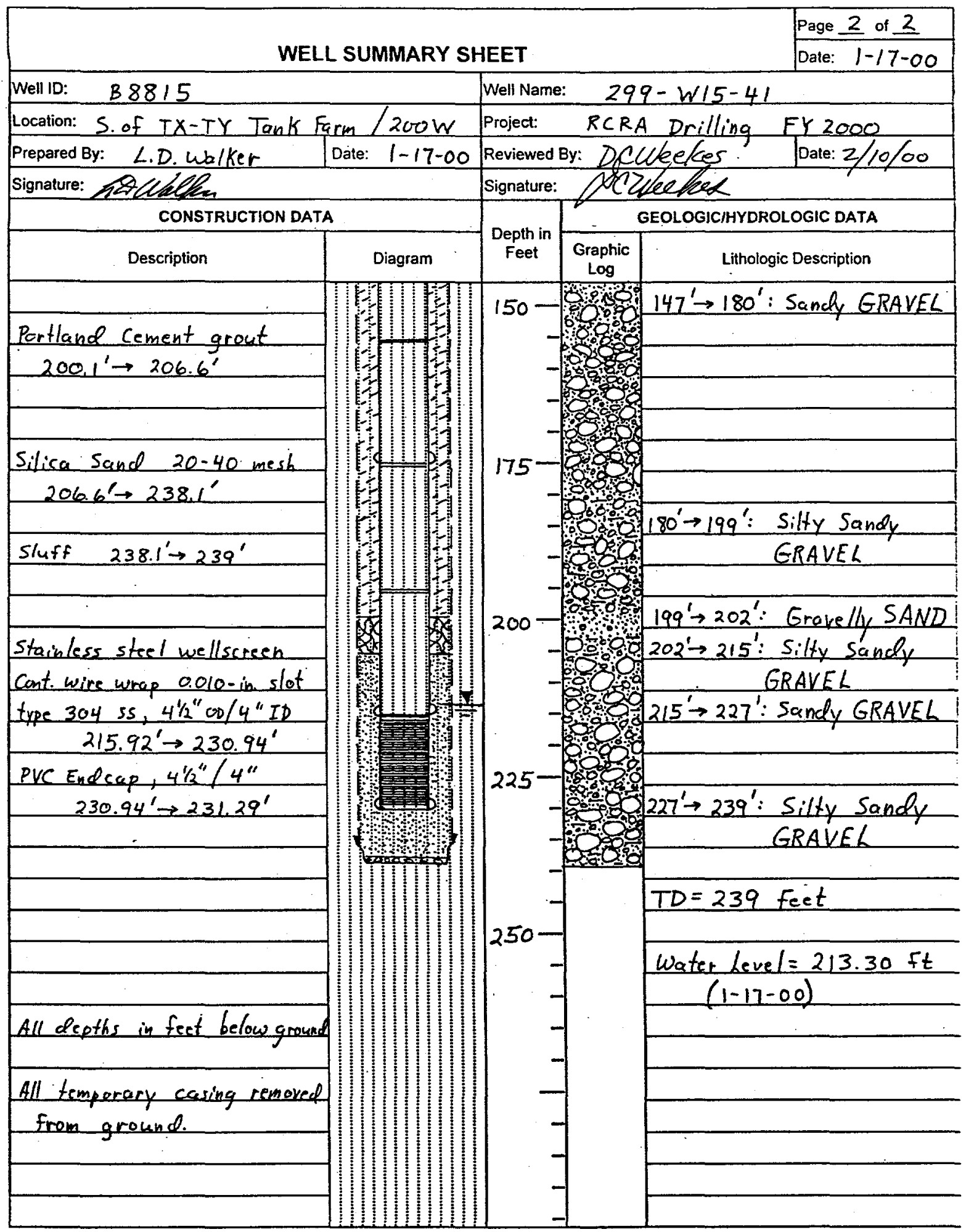

BHI-EE-189 (12/97) 


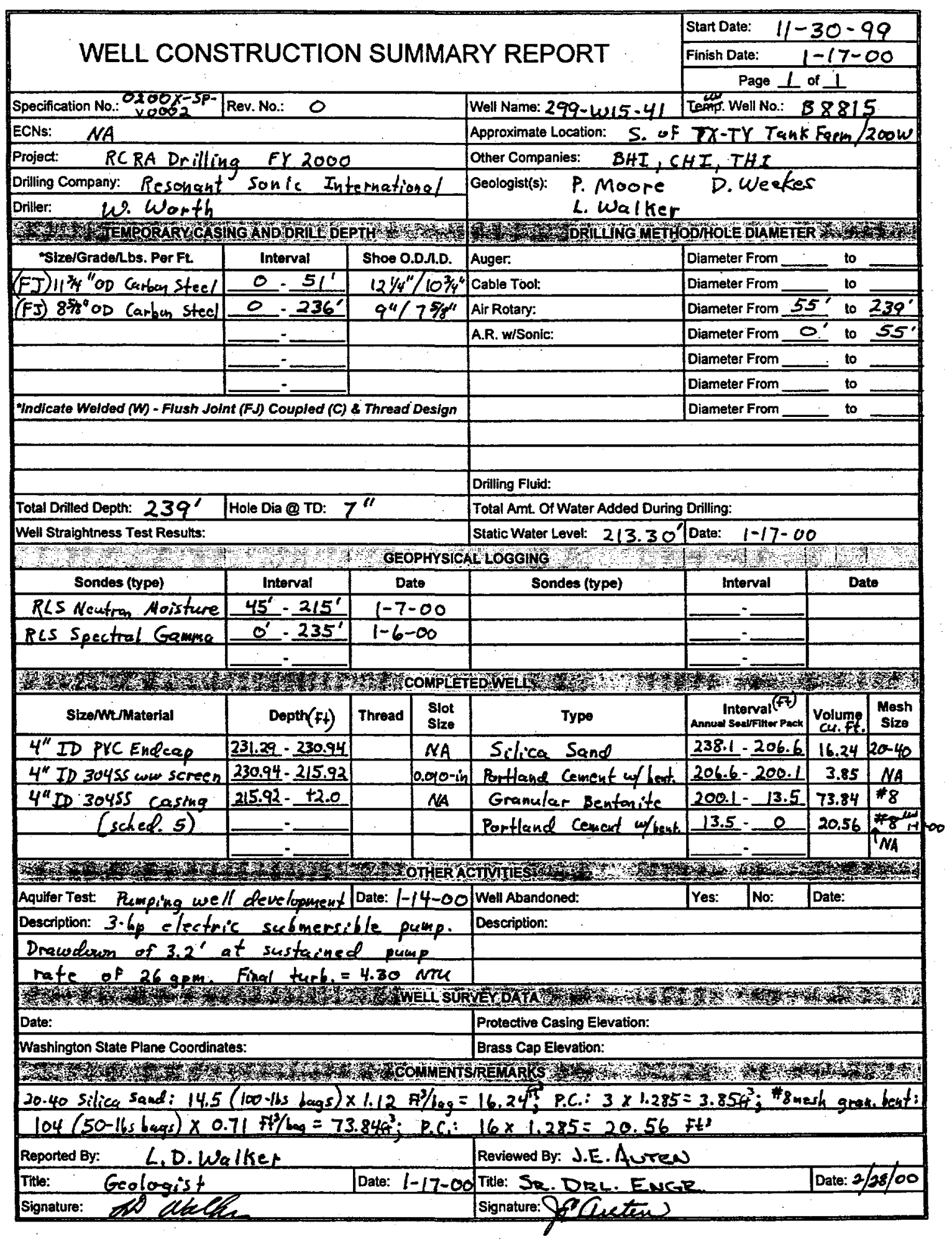

BHI-EE-181 (12997) 


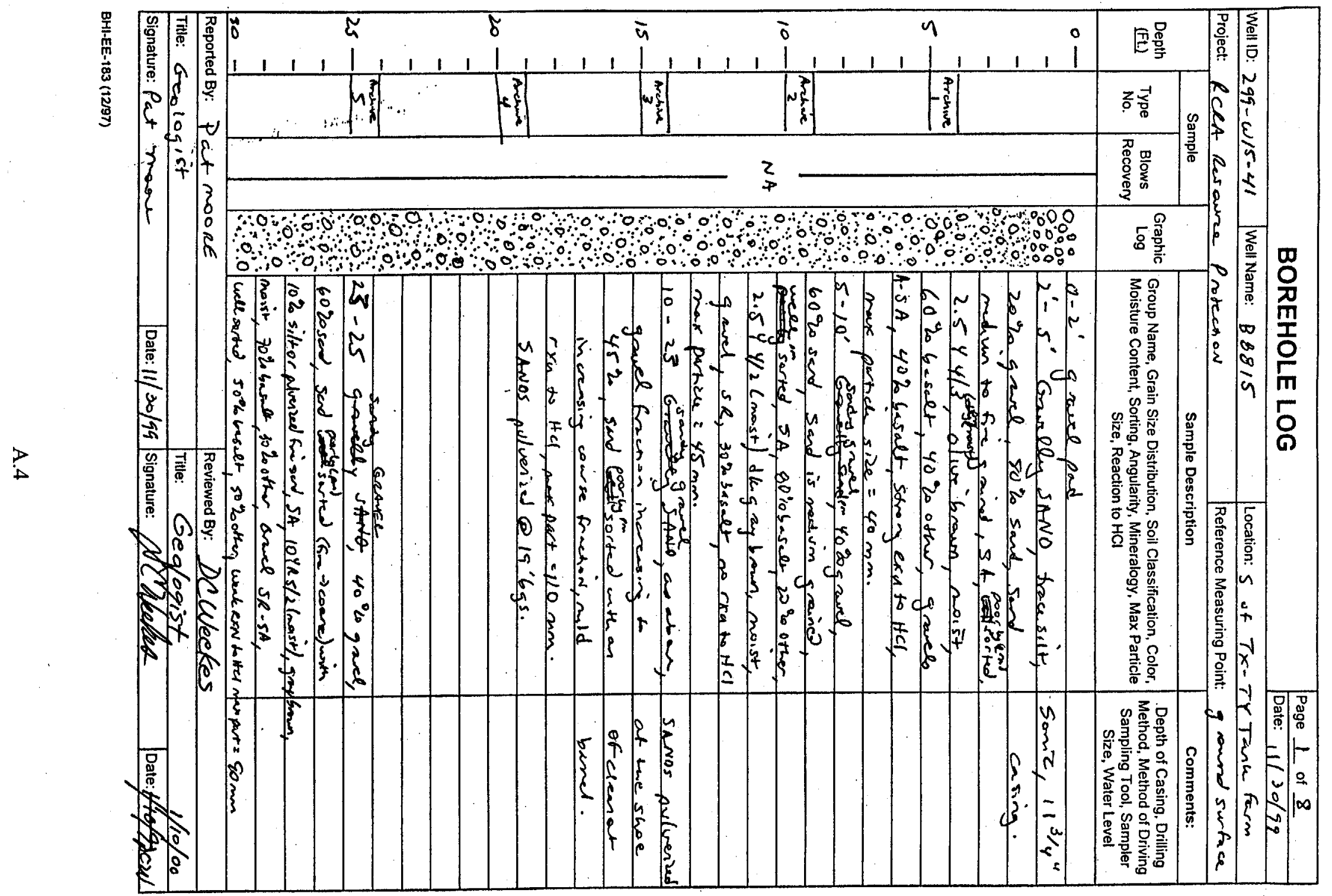




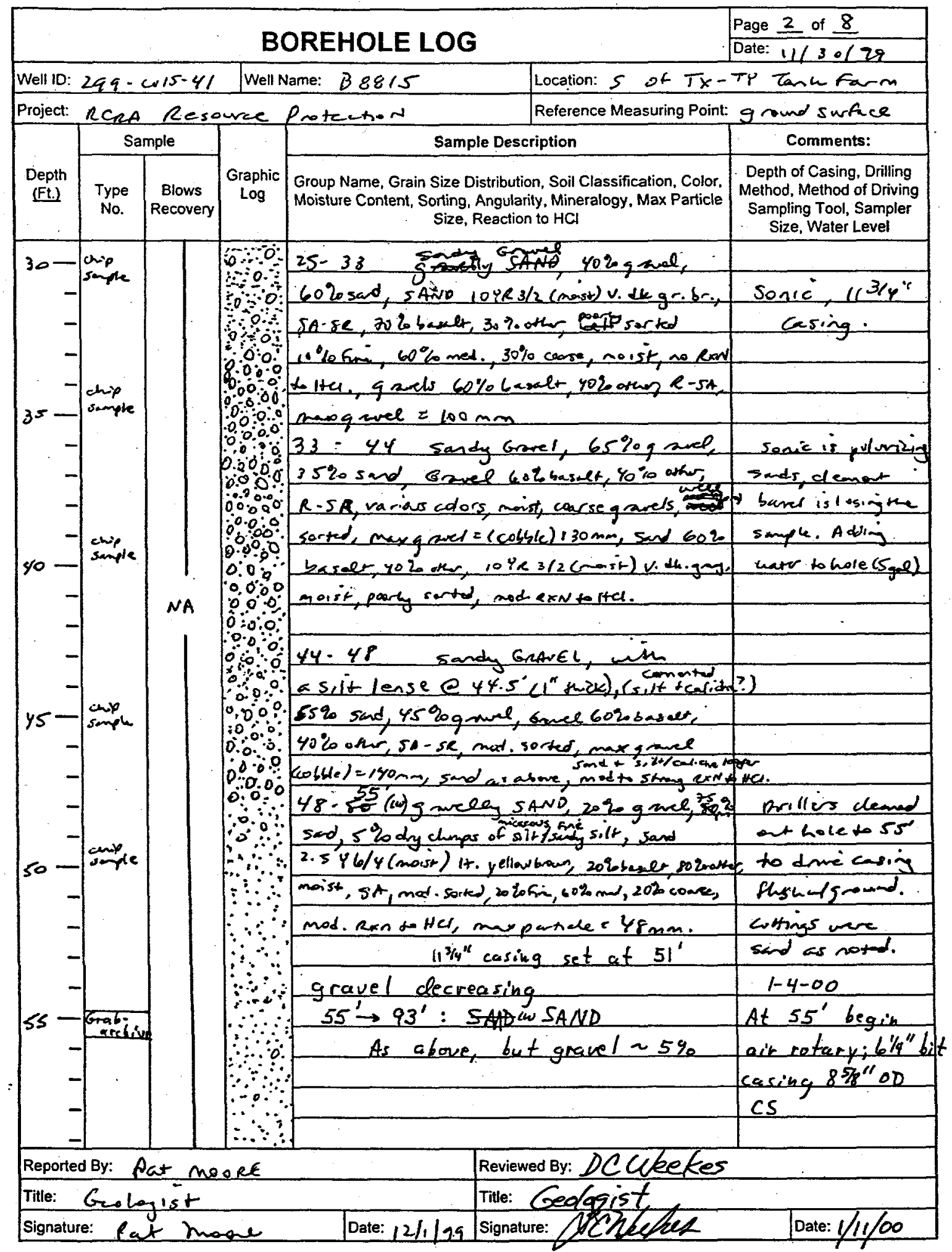

BHI-EE-183 (12/97) 


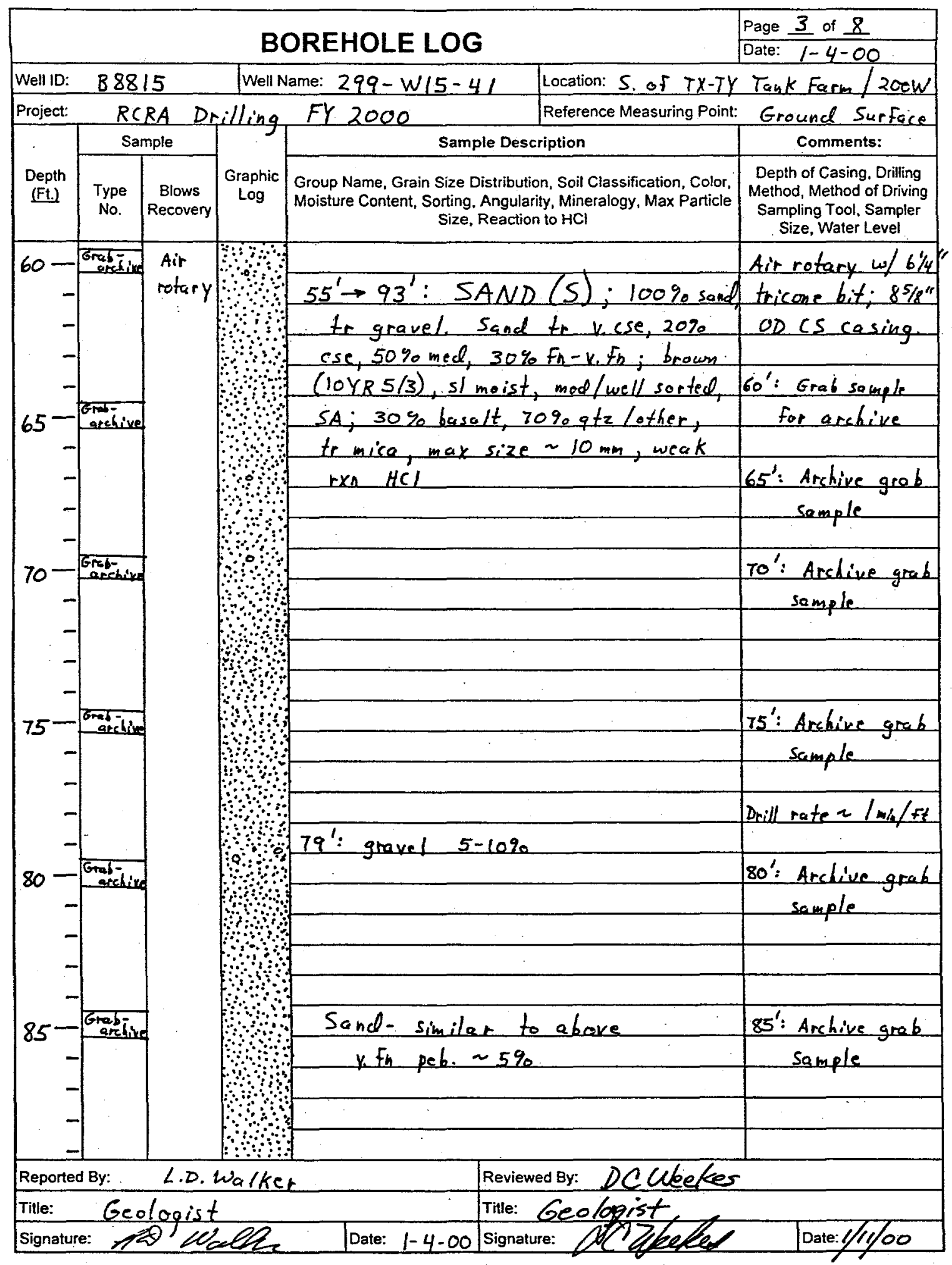

BHI-EE-183 (12/97) 


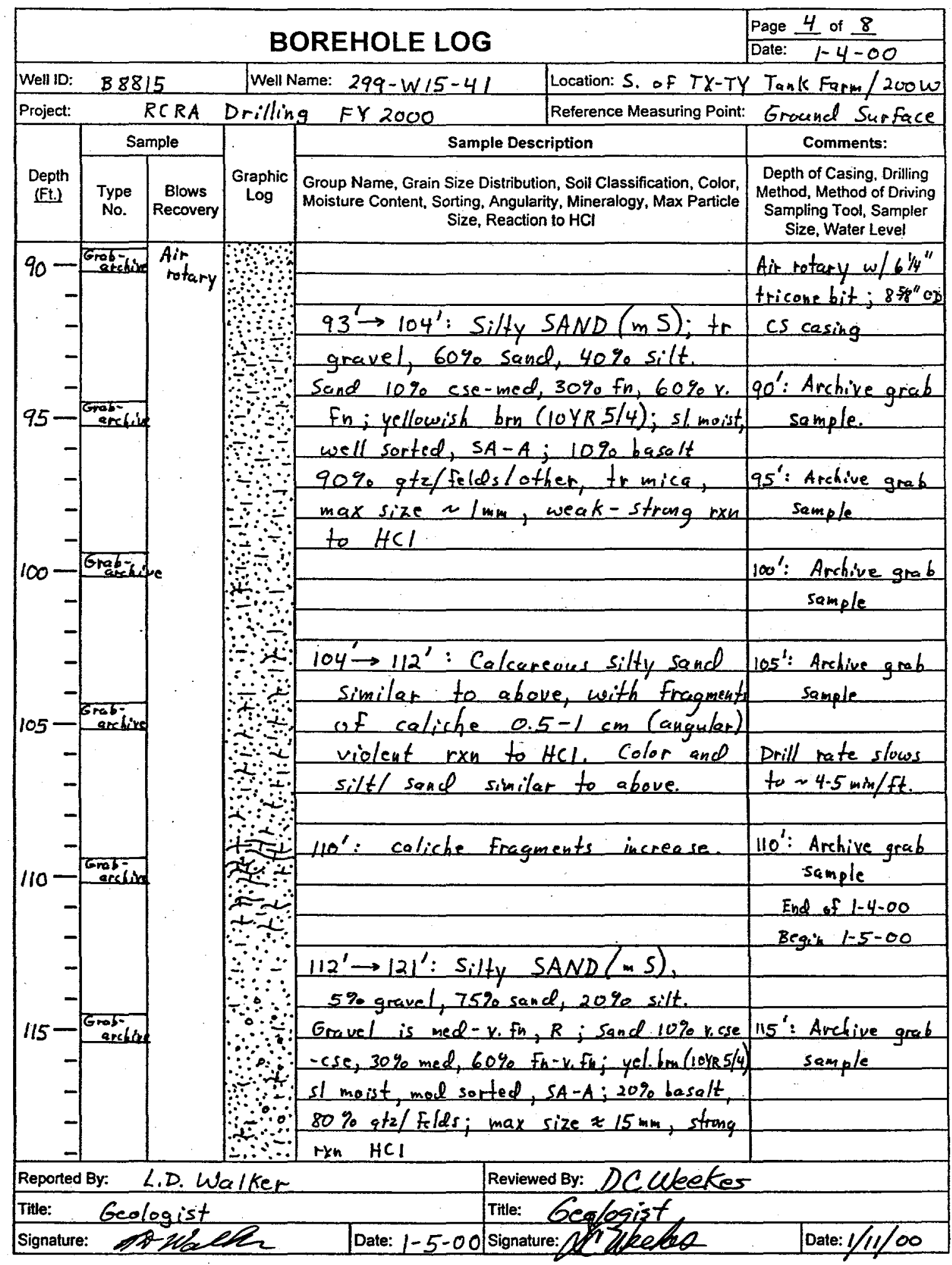

BHI-EE-183 (12/97) 


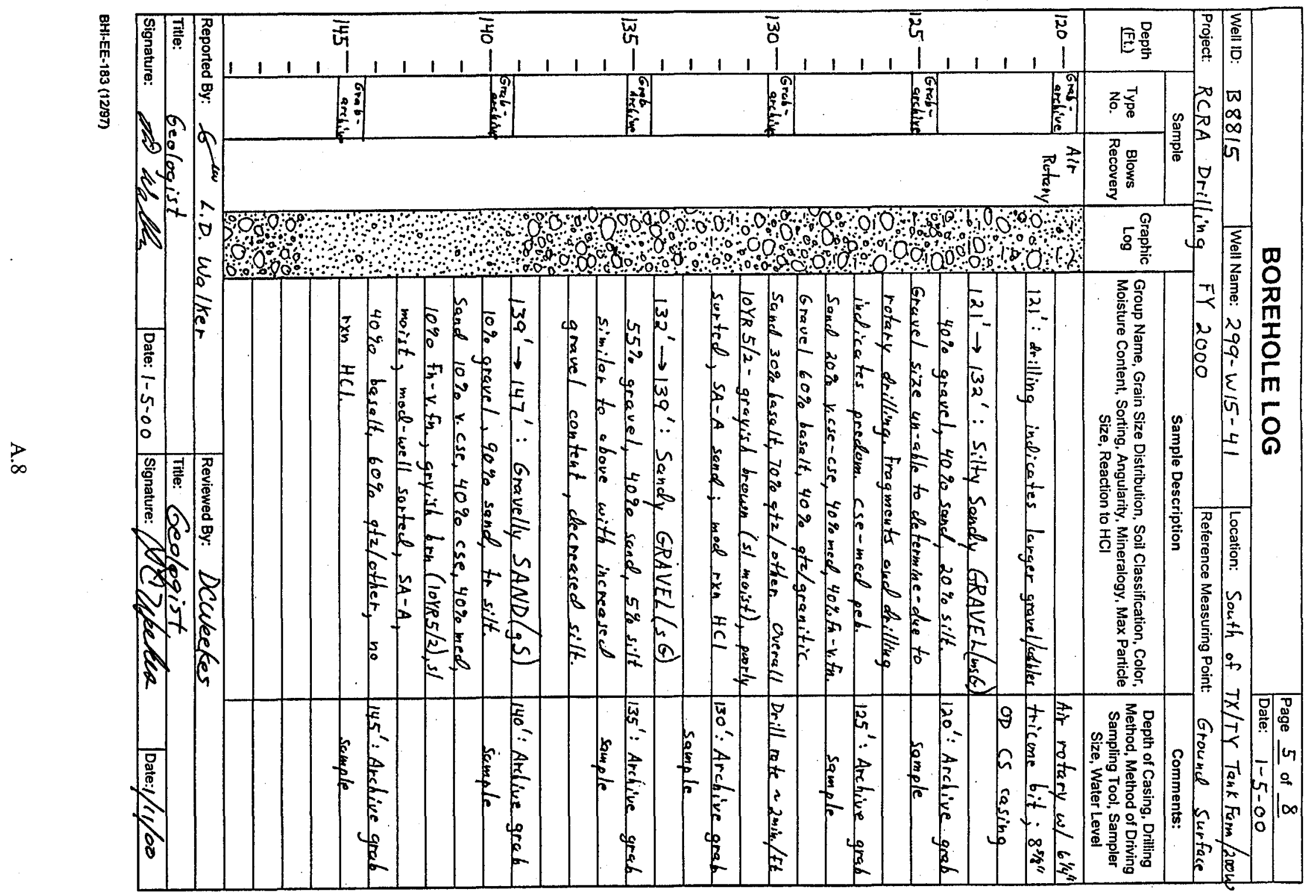




\begin{tabular}{|c|c|c|c|c|c|c|}
\hline \multirow[b]{3}{*}{ Well ID: } & \multirow{2}{*}{\multicolumn{5}{|c|}{ BOREHOLE LOG }} & \multirow{2}{*}{ Page $\frac{6}{6}$ of $\frac{8}{1-5-00}$} \\
\hline & & & & & & \\
\hline & \multicolumn{2}{|c|}{$B 8815$} & \multicolumn{2}{|c|}{ Well Name: $299-W|5-4|$} & \multicolumn{2}{|c|}{ Location: S. of TX-TY Tank Farm/200W } \\
\hline \multirow[t]{2}{*}{ Project: } & \multicolumn{2}{|c|}{ RCRA } & ling $F Y$ & 2000 & Reference Measuring Point: & Ground Surface \\
\hline & \multicolumn{2}{|c|}{ Sample } & \multirow[b]{2}{*}{$\begin{array}{c}\text { Graphic } \\
\text { Log }\end{array}$} & \multicolumn{2}{|c|}{ Sample Description } & Comments: \\
\hline $\begin{array}{l}\text { Depth } \\
\text { (Ft.) }\end{array}$ & $\begin{array}{l}\text { Type } \\
\text { No. }\end{array}$ & $\begin{array}{l}\text { Blows } \\
\text { Recovery }\end{array}$ & & \multicolumn{2}{|c|}{$\begin{array}{l}\text { Group Name, Grain Size Distribution, Soil Classification, Color, } \\
\text { Moisture Content, Sorting, Angularity, Mineralogy, Max Particle } \\
\text { Size, Reaction to HCl }\end{array}$} & $\begin{array}{c}\text { Depth of Casing, Drilling } \\
\text { Method, Method of Driving } \\
\text { Sampling Tool, Sampler } \\
\text { Size, Water Level }\end{array}$ \\
\hline \multirow{6}{*}{$\begin{array}{r}150- \\
- \\
- \\
- \\
155-\end{array}$} & Gaghishe & \multirow{28}{*}{ Air } & 860 & \multicolumn{2}{|c|}{$147^{\prime} \rightarrow 180^{\prime}:$ Sancly GRAVEL (sG) } & Air rotary w/ 61/4" \\
\hline & & & \multirow{4}{*}{ 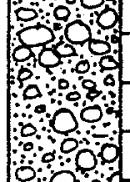 } & \multirow{2}{*}{\multicolumn{2}{|c|}{$\begin{array}{l}50-60 \% 0 \text { gravel, } 40-50 \% \text { sand, } \\
\text { tr silt. Gravel appears tr cobble, }\end{array}$}} & tricone bit; $85 \%$ \\
\hline & & & & & & OD CS casin \\
\hline & & & & \multirow{2}{*}{\multicolumn{2}{|c|}{$\begin{array}{l}20 \% \text { v.cse-cse peb, } 40 \% \text { med peb, } 40 \% \\
F_{n}-V_{n} F_{n} ; \text { Sand } 10 \% \text { v.cse-cse, } 30 \%\end{array}$}} & \\
\hline & & & & & & $150^{\prime}$ : Archive grab \\
\hline & \multirow[t]{5}{*}{ Gablive } & & \multirow{5}{*}{ 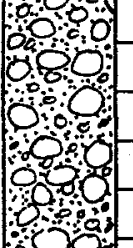 } & \multicolumn{2}{|c|}{$\operatorname{med}, 50 \% \mathrm{Fn}, 10 \%$ V.Fn. It brnish } & sample \\
\hline \multirow{5}{*}{-} & & & & \multirow{2}{*}{\multicolumn{2}{|c|}{$\begin{array}{l}\text { gray }(10 Y R 6 / 2) \text {, dry, poorly sorted, } \\
\text { gravel SR-SA; gravel } 50 \% \text { basalt }\end{array}$}} & \\
\hline & & & & & & 155': Archive grab \\
\hline & & & & \multirow{2}{*}{\multicolumn{2}{|c|}{$\begin{array}{l}50 y 0 \text { \& t } / \text { greaitic/other, sand } 15 \% \\
\text { basalt, } 85 \% \text { gtz; no } r \times n \text { HCl }\end{array}$}} & sample \\
\hline & & & & & & \\
\hline & & & ( & & & 160': Archive grab \\
\hline- & & & \%8: & & & Sample \\
\hline- & & & 80 & & & \\
\hline- & & & 80 & & & $165^{\prime}$ : Archive grab \\
\hline $165-$ & 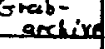 & & 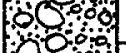 & $165^{\prime}:$ Sandy Gra & avel, as described & sample \\
\hline & & & 80 & above & & \\
\hline & & & \%o: & & & \\
\hline & & & $0 \%$ & & & 170': Archive \\
\hline & are & & $68: 0$ & $170^{\prime}:$ Sandy Gr & ravel, similat to abeve. & Sample \\
\hline & & & 50 & sand is pree & dem. Fn- $v$. Fn gtz rich & \\
\hline & & & 8 & gravel lower & basalt centeat than & \\
\hline & & & ion & above - now mo & esfy gtzite/grancitic & \\
\hline & & & 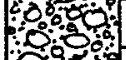 & It mice in & sand ; he tren $\mathrm{HCL}$ & 175": Archive grad \\
\hline $175-$ & $\begin{array}{l}\text { Grab- } \\
\text { atabive }\end{array}$ & & (n) & $175^{\prime}:$ gravel & 40 yo therwire as & semple \\
\hline & & & 8000 & above & & \\
\hline & & & 80 & & & \\
\hline & & & Opos & $178^{\prime}$ : slight ince & silt content & \\
\hline & & & ida & & & \\
\hline Reported & & L.D. & valker & & Reviewed By: DCukekes & \\
\hline Titile: & Geolo & & & & Title: Geologist & \\
\hline Signature & : $\Rightarrow$ & $\theta$ & $\overline{\mathbb{Z}_{4}}$ & Date: $1-5-00 \mathrm{~s}$ & Signature: $X 1$ Whe lex & Date: $1 / 11 / 00$ \\
\hline
\end{tabular}

BH-EE-183 (12/97) 


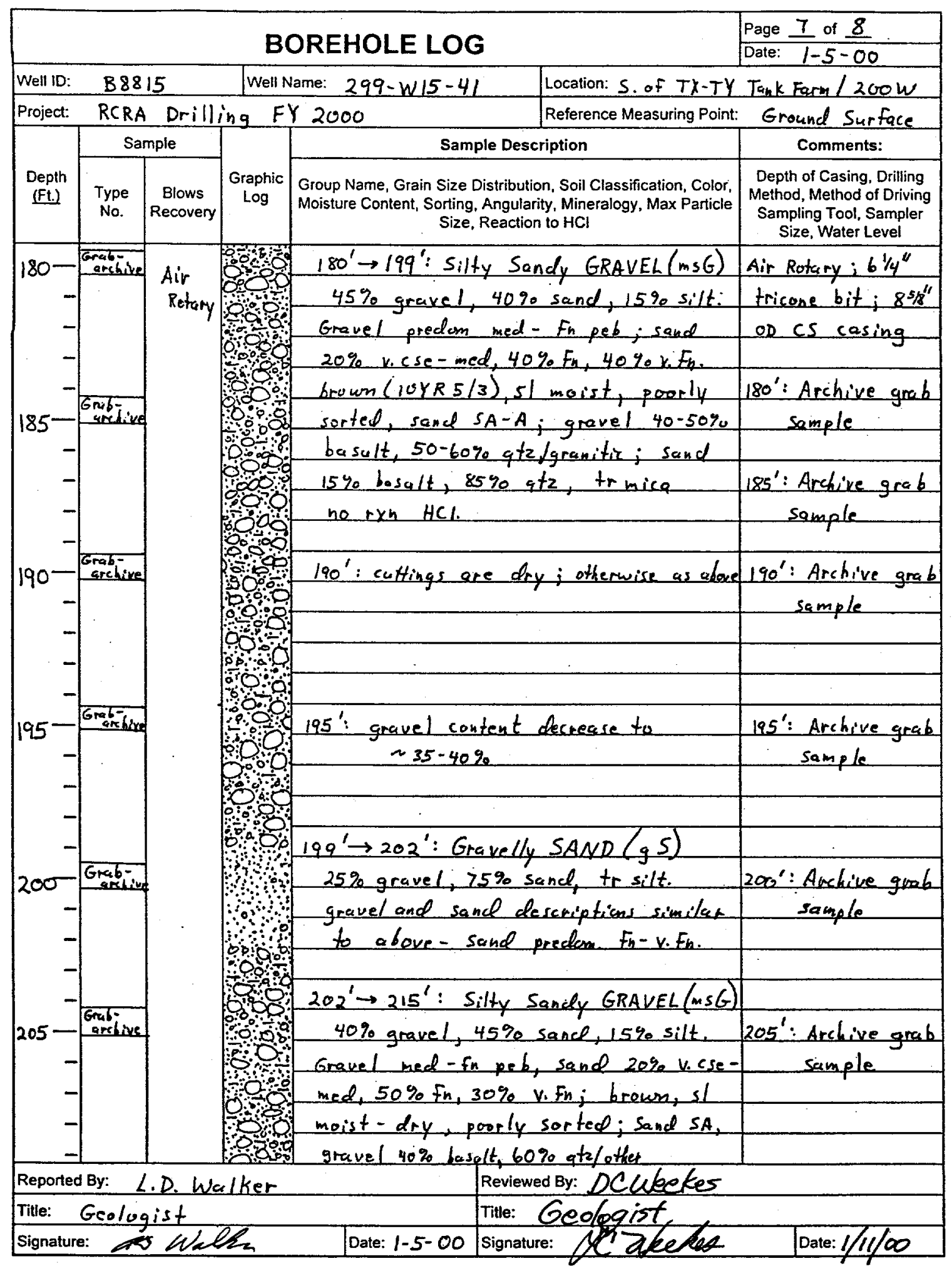

BHI-EE-183 (12/97) 


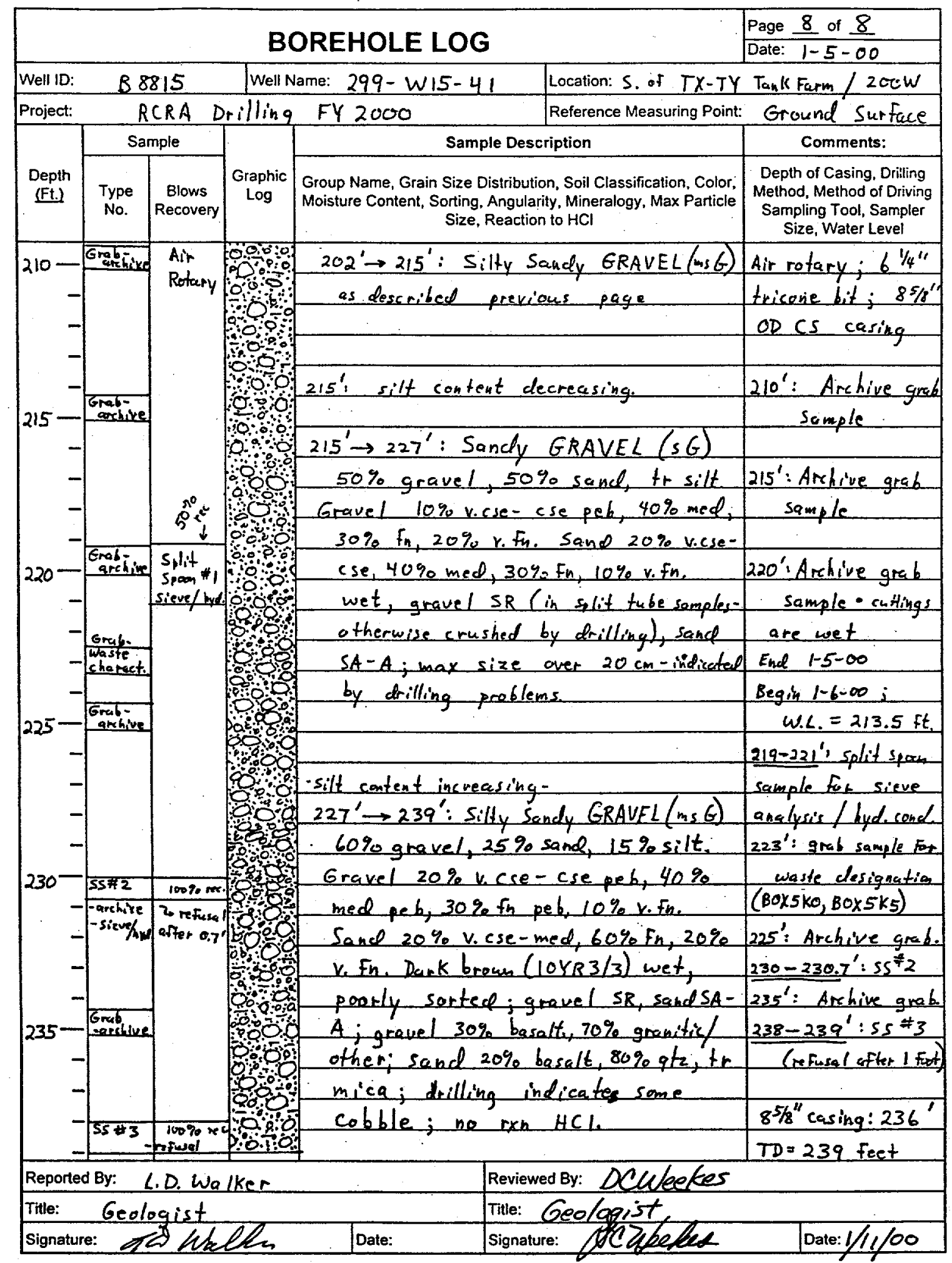

BHI-EE-183 (12/97) 
Appendix B

Borehole Geophysical Logs 


\section{Appendix B}

\section{Borehole Geophysical Logs}

This appendix contains the borehole geophysical logs obtained from borehole 299-W15-41. The logs were run and analyzed by Waste Management Federal Services Northwest, Inc. Included with the logs are Log Header Sheets and Log Analysis Summary Reports. 


\section{RLS Spectral Gamma Survey \\ Waste Management Technical Services}

\section{LOG HEADER}

Project: RCRA drilling 1999

Well: 299-W15-41

\section{Borehole Information}

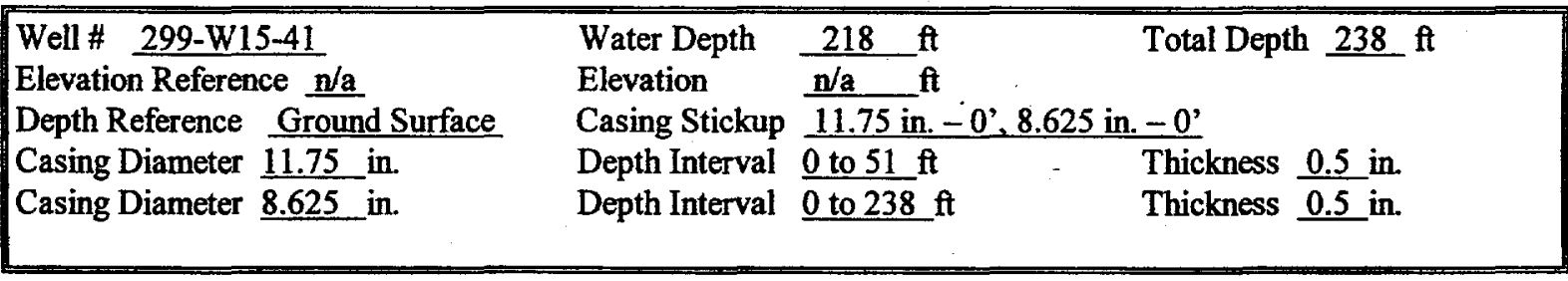

\section{Logging Information}

\begin{tabular}{|c|c|}
\hline Log Type: & HPGe Spectral Gamma \\
\hline Company & Waste Management Technical Services \\
\hline Logging Engineers & $\underline{\text { S.E. Kos }}$ \\
\hline Logging Date & January 6,2000 \\
\hline Instrument Series & RLSG07000S00.0 \\
\hline Logging Unit & RLS-1 \\
\hline Depth Interval & $\begin{array}{r}\text { Prefix A692 } \\
\text { A693 }\end{array}$ \\
\hline $\begin{array}{l}\text { Instrument Calibration Date } \\
\text { Calibration Report }\end{array}$ & $\begin{array}{l}\text { October } 8,1999 \\
\text { WHC-SD-EN-TI-292, Rev. } 0\end{array}$ \\
\hline
\end{tabular}

\section{Analysis Information}

$\begin{array}{ll}\text { Company } & \text { Waste Management Technical Services } \\ \text { Analyst } & \text { Steven Kos } \\ \text { Date } & \text { March } 15,2000 \\ \text { Depth Reference } & \text { Ground Surface }\end{array}$

Notes Measurements were acquired at $0.5-\mathrm{ft}$ depth increments at a logging speed of $1.0 \mathrm{ft}$ per minute. No manmade radionuclides were detected in this well. 


\section{RLS Spectral Gamma Survey}

Waste Management Technical Services

Project: RCRA Drilling 1999

Well: 299-W15-41
Log Date: January 6, 2000

Depth Datum: Ground Level

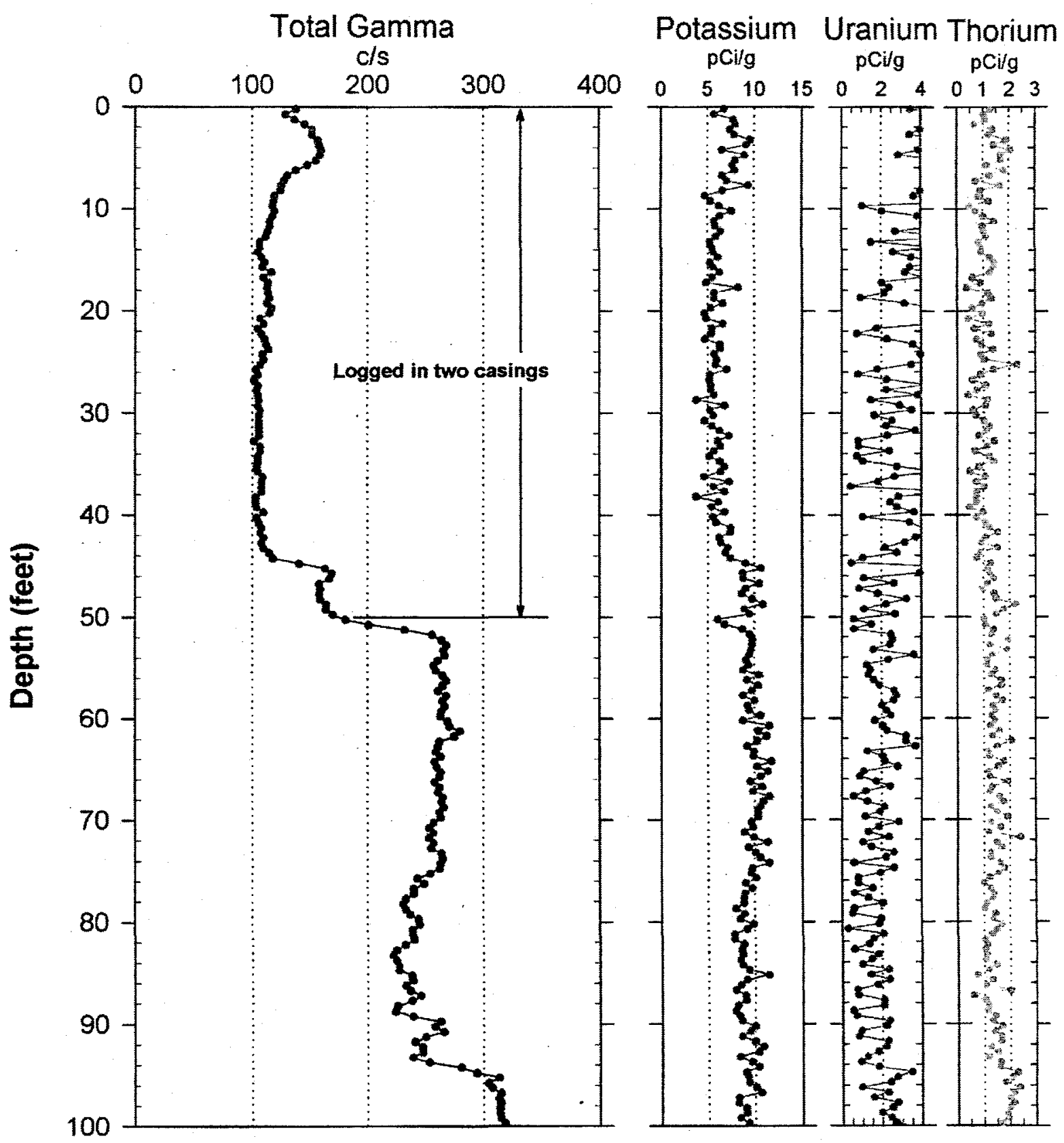

B.3 


\section{RLS Spectral Gamma Survey}

Waste Management Technical Services

Project: RCRA DRilling 1999

Well: 299-W15-41
Log Date: January 6, 2000

Depth Datum: Ground Level

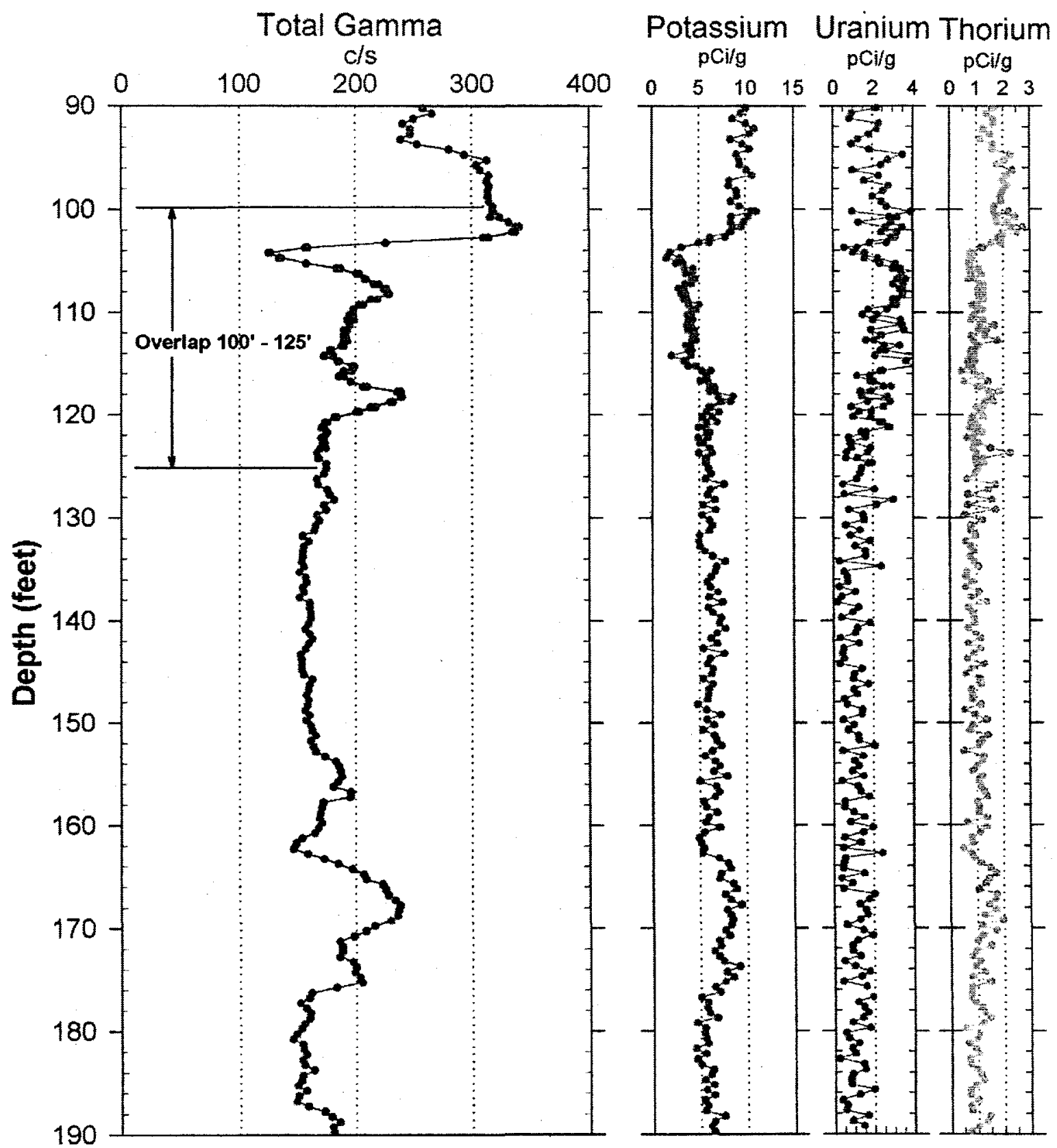

B.4 


\section{RLS Spectral Gamma Survey}

Waste Management Technical Services

Project: RCRA Drilling 1999

Well: 299-W15-41
Log Date: January 6, 2000

Depth Datum: Ground Level

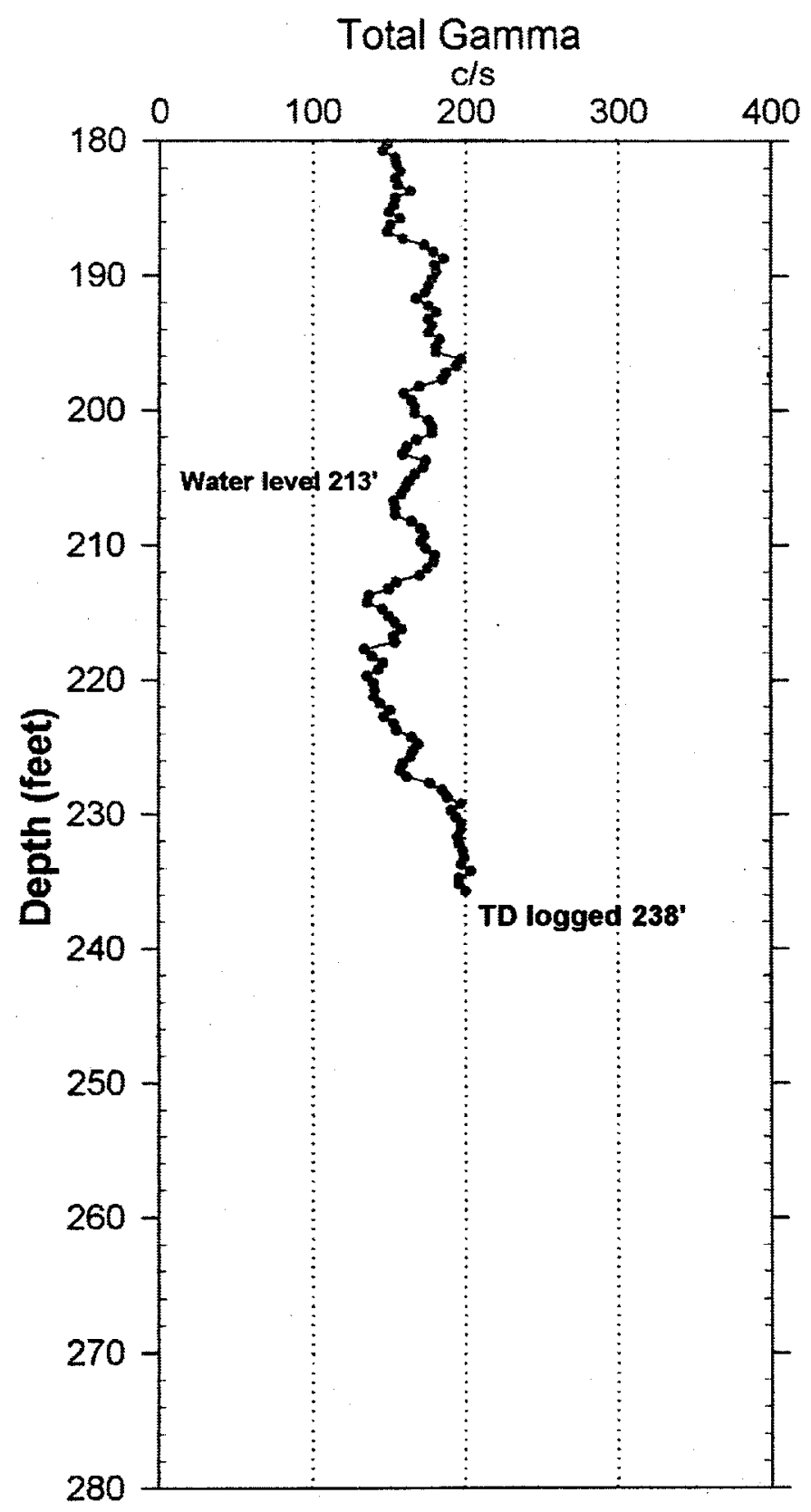

Potassium Uranium Thorium pCirg pCilg pCi/g

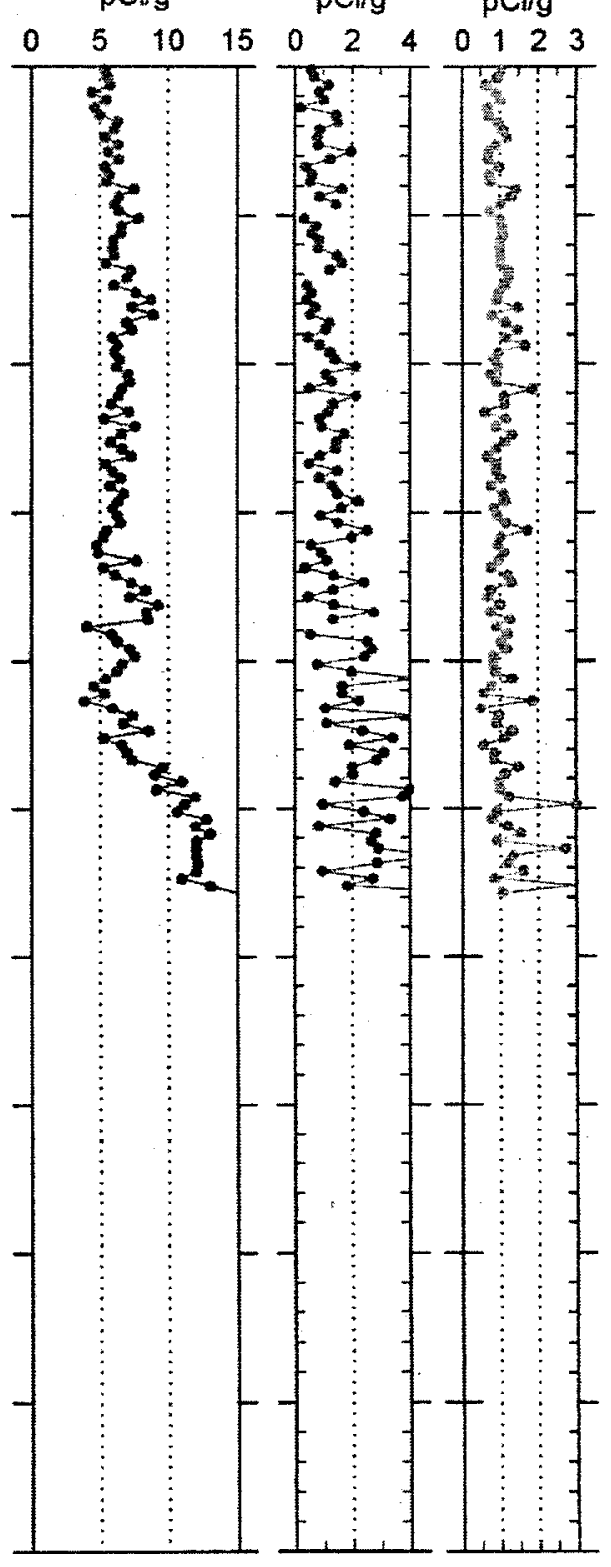




\section{RLS Spectral Gamma Survey \\ Waste Management Technical Services}

\section{Summary Report}

Project: RCRA Well Drilling 1999

Well: 299-W15-41

General Notes:

All log data were collected with reference to ground surface.

System Performance Verification: The pre- and post-log verification passed performance standards, indicating the system was performing to specifications outlined in the procedures.

Repeat Interval: Repeat surveys were conducted between depths of 100.0 and $125.0 \mathrm{ft}$. The results show good repeatability of measurements.

Environmental Corrections: The spectral gamma log measurements have been corrected for casing attenuation throughout the entire well, and a water correction was applied to the data acquired in the water to correct for the attenuation of water.

The interval from ground surface to a depth of $51 \mathrm{ft}$ was logged in double casings, and the lower concentrations result from the attenuation of the gamma rays.

\section{Observations:}

No man-made radionuclides were detected during the logging of this well.

The range of the concentrations of the naturally occurring radionuclides potassium-40 $\left({ }^{40} \mathrm{~K}\right)$, uranium, and thorium (KUT) are typical for Hanford formation and Ringold Formation sediments. The concentrations are, for the majority of samples, between 5 and $13 \mathrm{pCi} / \mathrm{g}$, between 0.5 and $4 \mathrm{pCi} / \mathrm{g}$, and between $0.5 \mathrm{and} 3 \mathrm{pCi} / \mathrm{g}$ respectively. Some erratic peaks are outside of these ranges, especially for uranium in the upper region of the borehole (at depths between ground surface and a depth of about $50 \mathrm{ft}$ ).

The profile of the total gamma plot, which is the sum of all counts in the spectra for each 0.5-ft depth sample, is most reflective of the ${ }^{40} \mathrm{~K}$ concentrations. However, the influence of uranium and thorium concentrations (more specifically the gamma rays) on the total gamma countrate can be seen in the region of the well between depths of about 94 and $120 \mathrm{ft}$; between depths of 164 and $170 \mathrm{ft}$; and from a depth of $228 \mathrm{ft}$ to the bottom of the borehole.

The most distinctive change in the total gamma $\log$ and the KUT concentration profiles (other than that observed at the bottom of the 11-in.-diameter casing) occurs between depths of 94 and $120 \mathrm{ft}$; this change is most likely indicative of a distinct lithologic change. The neutron-neutron moisture log data indicate that a lithologic change has occurred in this region of the borehole by a distinct change in volumetric moisture content at a depth of $95 \mathrm{ft}$; the volumetric moisture content in the sediments surrounding the borehole increases rapidly from about 4 percent to as high as 19 percent. Between depths of 95 and $120 \mathrm{ft}$, the moisture plot shows several narrow peaks of elevated moisture content that most likely indicate inter-bedded fine-grained materials that retain moisture. 


\section{RLS Neutron-Neutron Moisture Survey \\ Waste Management Technical Services}

\section{LOG HEADER}

Project: RCRA drilling 1999

Well: 299-W15-41

\section{Borehole Information}

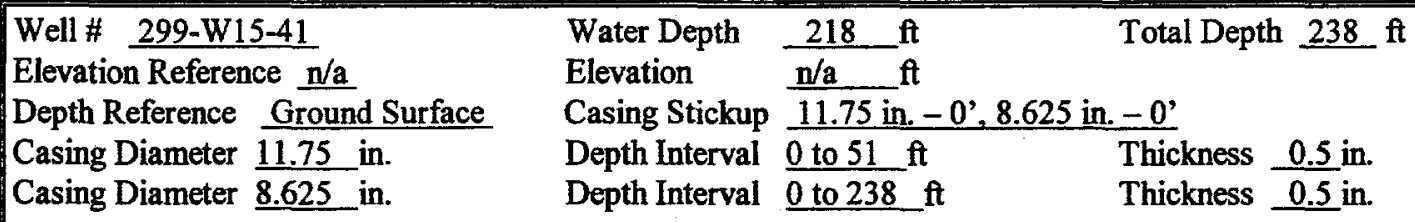

\section{Logging Information}

$\begin{array}{ll}\text { Log Type: } & \begin{array}{l}\text { Neutron-Neutron Moisture } \\ \text { Company }\end{array} \\ \text { Waste Management Technical Services } \\ \text { Logging Engineers } & \text { J.E. Meisner } \\ \text { Instrument Series } & \text { RLSM00.0 } \\ \text { Logging Date } & \text { January 7, 2000 } \\ \text { Logging Unit } & \text { RLS-1 } \\ \text { Depth Interval } & 45.0^{\prime} \text { to 120.0' } \\ & 100^{\prime} \text { to 215 } \\ \text { Instrument Calibration Date } & \text { May 13, 1999 MA52 } \\ \text { Calibration Report } & \text { WHC-SD-EN-TL-306, Rev. 0 }\end{array}$

Analysis Information

$\begin{array}{ll}\text { Company } & \text { Waste Management Technical Services } \\ \text { Analyst } & \text { Steven Kos } \\ \text { Date } & \text { March 13, 2000 } \\ \text { Depth Reference } & \text { Ground Surface }\end{array}$

Notes The moisture measurements were acquired at 0.250 -ft depth intervals at a logging speed of $0.6 \mathrm{ft}$ per minute. A repeat survey was conducted between depths of 100 and $120 \mathrm{ft}$. 


\section{Neutron-Neutron Moisture Survey}

Waste Management Technical Services

Project: RCRA Drilling 1999 Log Date : January 7, 2000

Borehole: 299-W15-41 Depth Datum: Ground Level

Moisture Vol. \%

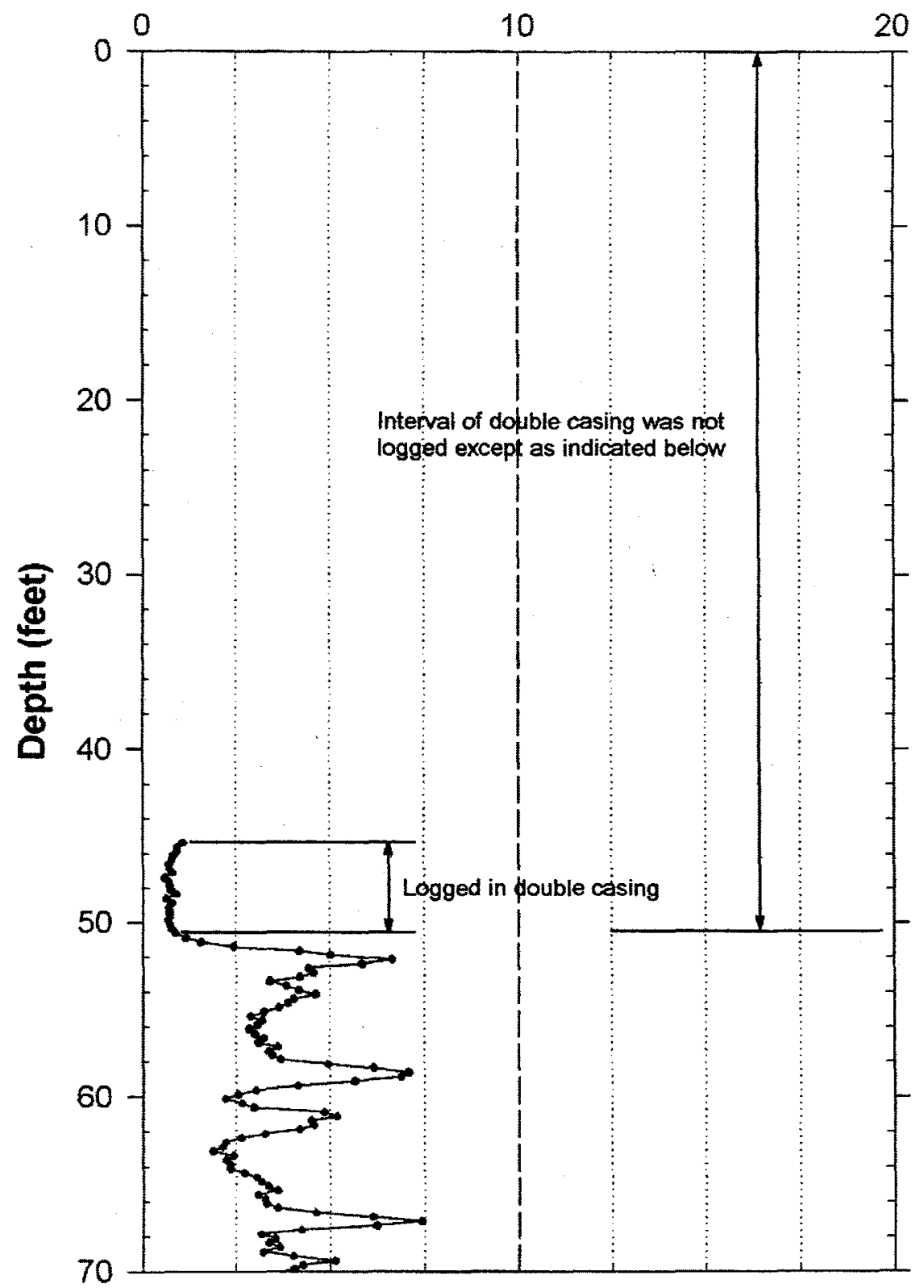

B.8 


\section{Neutron-Neutron Moisture Survey}

Waste Management Technical Services

Project: RCRA Drilling 1999 Log Date : January 7, 2000

Borehole: $299-$ W15-41

Depth Datum: Ground Level

Moisture Vol. \%

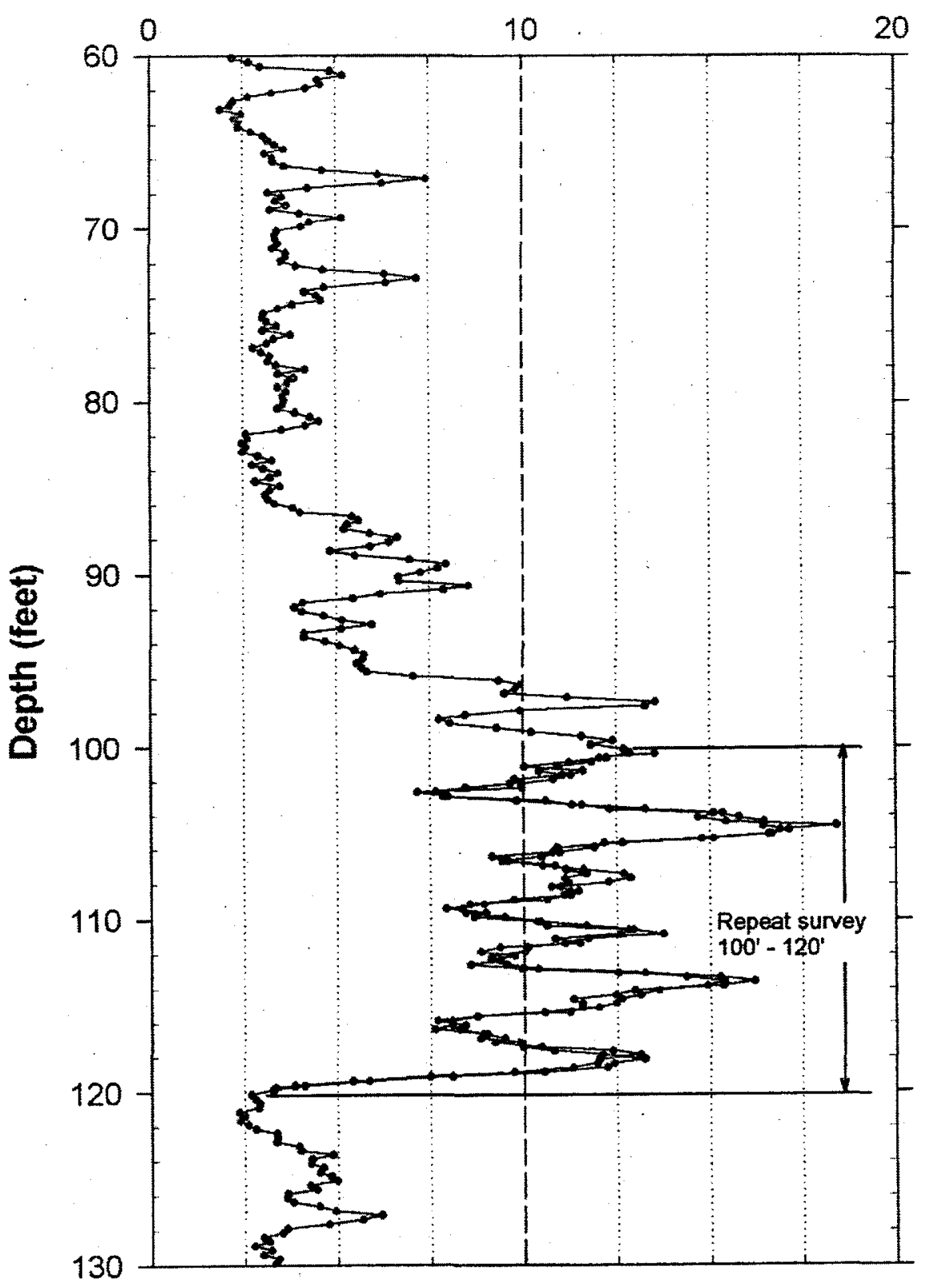

B.9 


\section{Neutron-Neutron Moisture Survey}

Waste Management Technical Services

Project: RCRA Drilling 1999 Log Date : January 7, 2000

Borehole: 299-W15-41

Depth Datum: Ground Level

Moisture Vol. \%

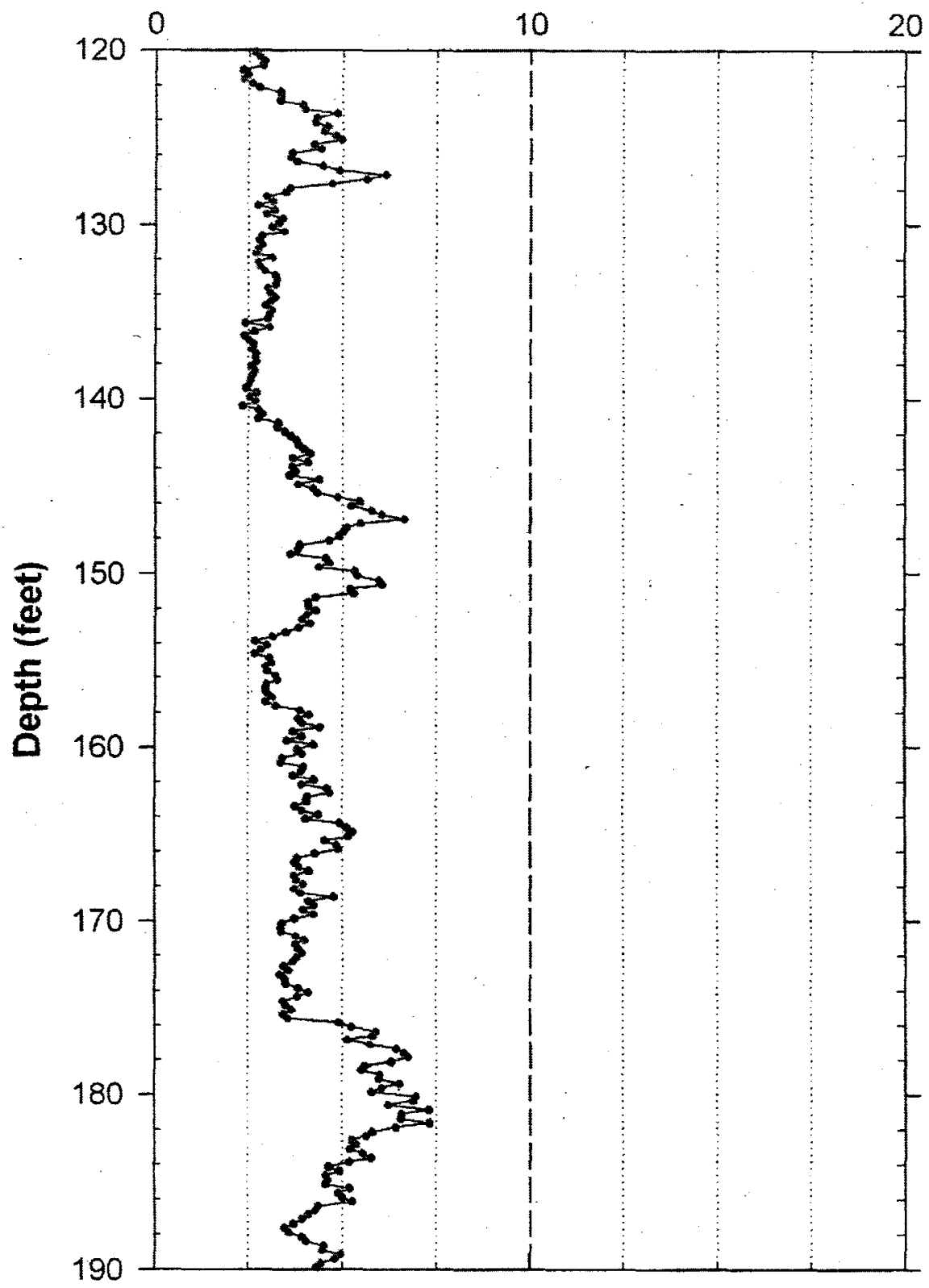

B. 10 


\section{Neutron-Neutron Moisture Survey}

Waste Management Technical Services

Project: RCRA Drilling 1999 Log Date : January 7, 2000

Borehole: 299-W15-41

Depth Datum: Ground Level

Moisture Vol. \%

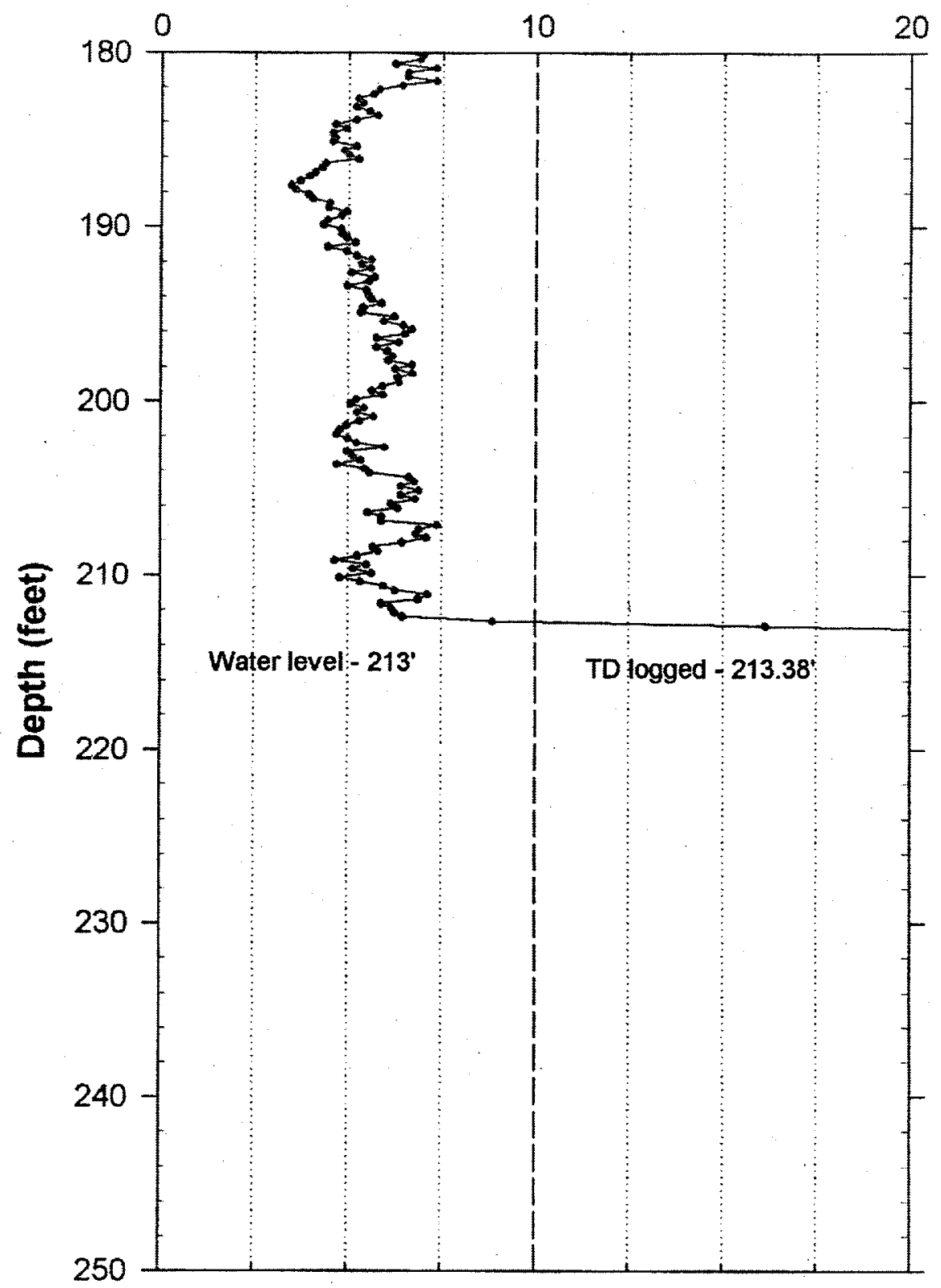

B.11 


\title{
RLS Neutron-Neutron Moisture Survey Waste Management Technical Services
}

\author{
Summary Report
}

Project: RCRA Drilling 1999

Well: $299-W 15-41$

\section{General Notes}

All $\log$ data were collected with reference to ground surface. The moisture survey was not conducted in the 11.75-in.-diameter casing (from ground surface to a depth of $51 \mathrm{ft}$ ) since the logging tool is not calibrated for this size casing. The survey was terminated at a depth of $213.38 \mathrm{ft}$ where groundwater was encountered.

System Performance Verification: The pre- and post-survey verification passed performance standards, $-3.4 \%$ in the shield verifier.

Repeat Interval: A repeat survey was conducted between depths of 100 and $120 \mathrm{ft}$. The results show good repeatability of the moisture profiles from the original and repeat surveys.

Environmental Corrections: The moisture measurements have been corrected for casing attenuation throughout the entire well. A casing correction for 8-in.-diameter casing was applied to the data.

\section{Observations}

The moisture values range from less than two percent volumetric moisture content at a depth of $63 \mathrm{ft}$, to as high as almost 19 percent volumetric moisture content at a depth of about $104 \mathrm{ft}$. The initial low values between depths of 45 and $51 \mathrm{ft}$ were acquired in double casings and are not valid measurements. These measurements can be utilized to determine the bottom of the double casing string, which is located at a depth of $51 \mathrm{ft}$.

The moisture values are highly variable between depths of 51 and $120 \mathrm{ft}$, as indicated by the many narrow peaks. These peaks most likely correlate with thin intervals of fine-grained sediments that retain moisture. The potassium, uranium, and thorium concentrations (as derived from the spectral gamma survey that was conducted in this borehole) vary in this region of the borehole; these variations are indicative of changes in lithology.

The moisture content increases (to an off-scale value) at a depth of about $213 \mathrm{ft}$ where groundwater is encountered. 


\section{Distribution}

No. of

Copies

OFFSITE

Confederated Tribes of the Umatilla Indian Reservation

Environmental Planning/Rights Protection

P.O. Box 638

Pendleton, OR 97801

ATTN: J. R. Wilkerson

L. Seelatsee

Wanapum Band

Grant County P.U.D.

30 "C" Street S.W.

P.O. Box 878

Ephrata, WA 98823

P. Sobotta

Nez Perce Tribe

Environmental Restoration/Waste

Management

P.O. Box 365

Lapwai, ID 83540-0365

Confederated Tribes and Bands of the Yakama Nation

Environmental Restoration/Waste

Management

2808 Main Street

Union Gap, WA 98903

ATTN: R. Jim
No. of

Copies

3 CH2M Hill Group

A. J. Knepp (3)

H0-22

2 CH2M Hill Hanford, Inc.

J. V. Borghese

H9-03

D. C. Weekes

H9-02

3 Washington State Department of Ecology

D. Goswami

B5-18

A. D. Huckaby

B5-18

S. Leja

B5-18

\section{U.S. Environmental Protection Agency}

D. A. Faulk

B5-01

16 Pacific Northwest National Laboratory

F. N. Hodges (3)

K6-81

D. G. Horton (3)

K6-81

S. P. Luttrell

K6-96

W. J. Martin

K6-81

B. A. Williams

K6-81

Information Release Office (7)

K1-06

\section{ONSITE}

\section{DOE, Richland Operations Office}

M. J. Furman (2)

A5-13

R. M. Yasek

H6-60

Distr.1 